QUALITY

Volume 5, Nomor 2, 2017: 375-385

\title{
ADAPTIVE MUTUAL CURRICULUM: A BREAKTHROUGH IN CHARACTER EDUCATION
}

\author{
Tedi Rohadi \\ IAIN Syekh Nurjati Cirebon \\ triaincrbn@gmail.com
}

\begin{abstract}
Abstrak
Pendidikan karakter dirasakan berbeda dan telah diimplementasikan secara parsial. Selain itu, pelaksanaannya dalam konteks kelas tampaknya mengacu pada konsep tingkat yang kemudian menyebabkan ketidakefektifan program. Oleh karena itu, referensi atau panduan dalam bentuk kurikulum yang berlaku diharuskan. Penelitian ini bertujuan untuk menciptakan model kurikulum bersama adaptif yang dapat memberikan panduan praktis yang jelas bagi para guru dalam menerapkan pendidikan karakter dan memvalidasinya. Kurikulum adaptif bersama sebagai produk studi disesuaikan dengan kebutuhan kontekstual, kondisi aktual dan aktual, dan persyaratan perkembangan yang diadopsi. Desain dan isi kurikulum dirancang dan ditentukan oleh konteks eksternal pengajaran dan pembelajaran. Adaptasi dilakukan pada awal dan sementara proses pelaksanaannya. Rancangan kurikulum adaptif bersama adalah aktualisasi dalam bentuk tujuan, isi atau bahan, pengalaman belajar, dan evaluasi yang diwujudkan dalam bentuk manual kurikulum dan bahan ajar serta kegiatan bagi siswa. Terlepas dari kelemahan dan masalah yang dimiliki kurikulum bersama adaptif, namun pada tingkat tertentu terbukti menjadi model kurikulum yang divalidasi dalam pendidikan karakter.
\end{abstract}

Kata kunci: model, pendidikan karakter, adaptif mutual curriculum, implementasi

\begin{abstract}
Character education is perceived differently and has been implemented partially. In addition, its execution in classroom context seems to simply be on the concept level which later on leads to the ineffectiveness of the program. Therefore, a reference or guidance in the form of applicable curriculum is necessitated. The study seeks to create a model of an adaptive mutual curriculum that can provide a clear cut practical guidance for teachers in implementing character education and validates it. The mutual adaptive curriculum as the product of the study in its implementation is adjusted to contextual needs, real and existing condition, and adopted developmental requirements. The design and content of curriculum is designed and determined by the external contexts of teaching and learning. The adaptation is carried out in pre and whilst the process of the implementation. The design of mutual adaptive curriculum is actualized in the forms of objectives, content or materials, learning experiences, and evaluations which are realized in the form of curriculum manual and instructional materials and activities for students. Despite the weaknesses and
\end{abstract}


the problems that the mutual adaptive curriculum has, it has in certain extent proven to be a validated model of curriculum in character education

Key words: model, character education, adaptive mutual curriculum, implementation

\section{A. Introduction}

The point of departure of the study is based on some crucial and multidimensional crisis. In national context, nationalism and national self-esteem have been faded away. The disintegration indication seems to grow. The human resources quality is indicated to be lower than the other nations. Above all, the Indonesian education system tend to more focus on cognitive aspects lacking character building. In school context, the number of student delinquent behaviors such as fighting/brawl, bullying, the use drugs and alcohol, permissiveness, and free sex among students seems to increase year by year. In response to those phenomena, character education is one of the solutions.

Education is the process of producing human beings who have a noble character, in addition to academic ability and skills. One way to realize it is to integrate character education in all learning. The main character values, such as honesty, intelligence, strength, and care, should be embodied in the attitudes and behaviors of students. It is in line with The Law No.20 year 2003 of National Education System which explains:

"education means conscious and well-planned effort in creating a learning environment and learning process so that learners will be able to develop their full potential for acquiring spiritual and religious strengths, develop self-control, personality, intelligence, morals and noble character and skills that one needs for him/herself, for the community, for the nation, and for the State " (Depdiknas, 2003).

Character is defined differently from one theorist to other theorist. Aristotle defined good character is defined by Aristotle as the life of right conduct in relation to others and to oneself (Lickona, 1992). According to Elkind and Sweet (1997), character is defined as the types of choices people make. Finally, Lickona stated that good character was defined to comprises of moral knowing, moral feeling, and moral 
behavior. In other words, knowing the good, desiring the good, and doing the good were what constituted good character. Therefore, character is based or judged on how one behaves through the choices or decisions he/she makes.

Regarding character Education, it is perceived and defined variously. Character education is defined as (1) the development of a language with students that instilled universal values that were worldwide (Rusnak, 1998), (2) strategic instruction that promotes social and personal responsibility and the development of the good character traits and moral virtues that make this possible (Vessels and Boyd, 1996). (3) formal instruction in honesty, trust, cooperation, respect, responsibility, hope, determination, and loyalty (Fertman and van Linden, 1999), (4) everything the school did to help students make better, more effective choices and decisions; the students must identify, understand, and learn how to act on their own values (Tomaselli and Golden, 1996), (5) as "the long-term process of helping young people develop good character, i.e. knowing, caring about, and acting on core ethical values such as fairness, honesty, compassion, responsibility, and respect for self and others" (p. 3) (Schaeffer (1999) in the Character Education Partnershi), (6) teaching students how to make good choices (Elkind and Sweet, 1997). From those definition, character education character education can be summarized as whatever schools did to influence how students think, feel, and act regarding issues of right and wrong (Mathison,1998).

In the context of this study, one way to implement character education is via character education curriculum since it directs the content standards, standards of competence, basic competence, the syllabus, lesson plans, teaching materials, procedures and evaluation of character education in schools. In addition to that, character education curriculum is the concept of a curriculum that is designed as a learning experience. In this context, the curriculum is not sense in terms of material, but rather a learning experience that is designed for learners. Correspondence to this, Caswel and Campbell in Zais (1976) stated that the curriculum is all the experience of the children under the guidance of a teacher. 
The same thing also expressed by Print (1993: 5) who explains that the curriculum is learner experience gained in the context of the education including unplanned curriculum or called the hidden curriculum. In this case, it means that the curriculum is all the things that are designed by the school to be followed by the child during this particular education, in the form of a number of learning experiences for students. So based on this definition, the school will be able to design a learning program that can be followed by students in accordance with the educational objectives that have been planned in advance.

In designing a learning experience, then the curriculum needs to be developed intensively by education practitioners. In curriculum development, there are a number of models proposed by curriculum experts. Print (1993:85) explains that in the process of developing a curriculum there are a number of steps that need to be explained sustainably. It cyclically starts from analyzing the situation, the purposes, content, learning experience until establishing the evaluation.

The approach in designing the implementation of character education is through mutual adaptation. In other word, character education is adapted to existing teaching of religion education (PAI). Its implementation is characterized by the adjustments to contextual needs, real and existing condition, and developmental requirements. The adaptation result in mutual adaptive curriculum.

\section{Methods}

The study is classified into research and development. It uses the ADDIE development model which consists of five phases: Analysis, Design, Development, Implementation, and Evaluation. The study is conducted at three junior high schools: SMPN I Kota Kuningan, SMPN I Kota Majalengka, and SMPN I Indramayu. The qualitative and quantitative data of the study are analyzed qualitatively and quantitatively.

\section{B. Result and Discussion}


The product of the study is mutual adaptive curriculum. Mutual adaptive curriculum is relevant in developing Islam religion education teaching and character education. According Jackson (1991: 428), the approach is characterized by its implementation in which adjustments to contextual needs, real and existing condition, and developmental requirements are adopted. It is due to the fact that curriculum could not empirically be implemented thoroughly as planned instead of being adapted to local needs.

Curriculum as document is provided by the government consisting of varieties of sciences and values. The school stakeholders are required to adapt/adjust the curriculum to socio-cultural aspects adopted by the school before being implemented. The design and content of curriculum is designed and determined by the external contexts of teaching and learning. The adaptation is carried out before and during the process of the implementation.

Basing on adaptive approach, teachers are given more freedom to develop, plan, implement, and evaluate the curriculum so as to be more relevant to the development of students' characters. Teachers of Islam religion education can design the material not only related to the Islam religion teaching but also to character education comprising of moral knowing,, moral feeling, and moral action as shown in the scheme below

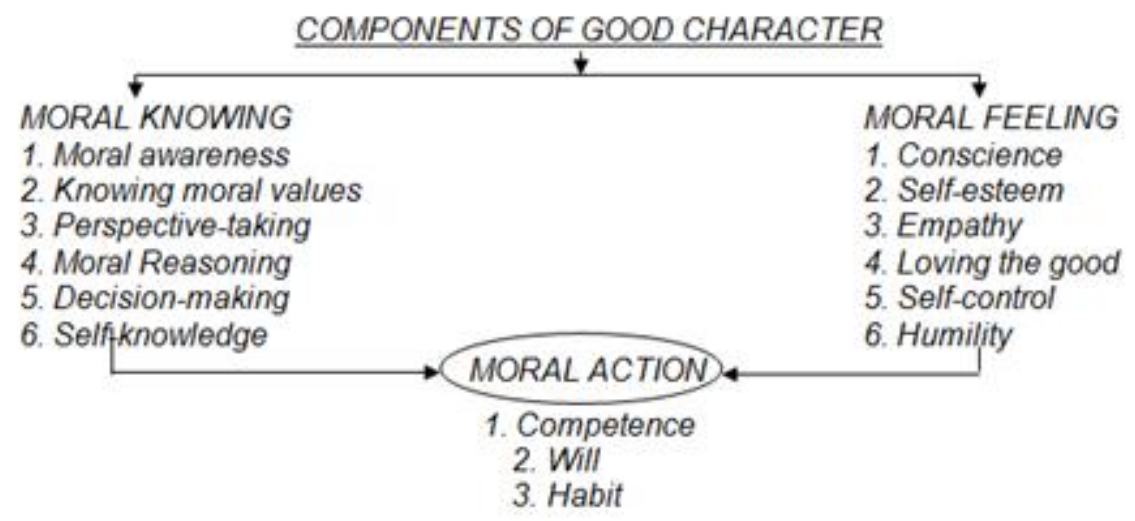

Scheme 1 Components of Good Characters 
Moral knowing is carried through dialogic. In addition, moral feeling is conducted through students' direct experience in their social and personal lives. Finally, Moral action covers every school effort in establishing the pillars of character education to come into reality. In implementing moral action, the schools should take into account competence, willing, and habit in school premises.

The development of mutual adaptive curriculum in three junior high schools is done through the stages prescribed in ADDIE development model. There are five sequential stages: first, need analysis; second; design; third, development; fourth, implementation; and fifth, evaluation. In need analysis, the analysis is focused on a learner analysis, goal analysis, context analysis, and content analysis.

The result of the analysis indicate that most of the teachers and students assume that character education is an important thing for students, but the implementation is still not optimal because most teachers are still not able to integrate the characters in the learning activity. In addition, the characters that are needed to be instilled are made up of 18 character values formulated by the Ministry of Education (1) religious, (2) honest, (3) tolerance, (4) Discipline, (5) hard work, (6) creative (7) independent, (8) democratic, (9) curiosity, (10) nationalism, (11) nationality pride, (12) rewarding achievement, (13) friendly/communicative, (14 ) love of peace, (15) joy of reading, (16) environmental care, (17) social care, (18) responsibility (Kemendiknas, 2010).

Besides those characters, some characters derived from Islamic education teaching are also enacted such values as submissiveness to God, discipline, sensitivity to religious values, respect to parents and teachers, self-fulfilled, good conduct to brothers/sisters/friends/newly known person. Last but not least, some local wisdom are as well included in term of proverbs and wise words.

Furthermore, the result of the context analysis shows that that the character education that took place during the school environment is not supported by many surrounding communities of environmental schools and families. As a result, it makes the process of education has not been a comprehensive character. 
The design of mutual adaptive curriculum is actualized in the forms of objectives, content or materials, learning experiences, and evaluations which are realized in the form of curriculum manual and instructional materials and activities for students. Curriculum manual provides a general guideline in the implementation of character education in junior high school and a guidance for the teacher in implementing character education in classroom teaching. Instructional materials and activities consists of materials and activities that support the teaching and learning and development of students' characters.

The mutual adaptive curriculum is composed of such components as: community participation, character education policy, defined-traits, integrated curriculum, the connection between the traits you have chosen and classroom lessons, experiential learning, include community-based, real-world experiences, evaluation, adult role models, staff development, student involvement, sustaining the program. The mutual adaptive curriculum makes all stakeholders participate in order to create consensus and a school formal policy. In the implementation, first, character education has to be integrated at all grade and on school subjects. Second, students are exposed in real life situation which include community and real-world experiences. Third, evaluation is intended to find whether the program is affecting positive changes in student behavior, academic achievement and cognitive understanding of the traits and the implementation process is providing the tools and support teachers need. Fourth, adult role models is important that adults demonstrate positive character traits at home, school and in the community. Fifth, staff development is required to create and implement character education on an ongoing basis. Sixth, students involvement should be encouraged to make them connected totheir learning, decision-making and personal goals. Finally, the program of character education can only be sustained unless there is a high level of commitment from the top: adequate funding; support for district coordination staff; high quality and ongoing professional development; and a networking and support system for teachers who are implementing the program 
The development process of mutual adaptive curriculum get through some activities. The data obtained from curriculum experts, observation, and interviews with teachers and students are the main consideration especially for the selection and development of characters to be developed. The learning experience is designed in a short time which is 10-20 minutes every day. The design of these activities is the design of the child's daily activities are initiated from a child waking up in the morning, preparing to leave for school, activities at school to return to her home. Researcher creates a simple design activity that could be implemented by the child's day-to-day. Later on, curriculum that has been developed which is further validated by the expert curriculum specialists who aim to look at the suitability of the formulation of the components of the existing curriculum, expert look at the suitability of the material formulation of educational materials designed character. The formulation of the material is also seen conformity with the characteristics of their students. Further validation is also performed by language linguists.

Soon after the model has been validated, it is implemented in three junior high schools. Implementation of activities performed each day learning to take time in the middle or at the end of the lesson learning. In the implementation phase of the student activities, the students with the help of teachers are doing activities that have been designed to guide the student.

The evaluation of the model is conducted through the validation and refinement of the results of the implementation so that the final product is ready to be tested more widely. The evaluation results more in terms of the language used primarily devoted to elementary school age children. The effectiveness and practicalities of the curriculum are tested by conducting tests on three schools that have been designated. It results in relatively effective and practical.

There are some problems faced in implementing the adaptive mutual curriculum. As indicated at the stage of analysis stating that the environmental context affects the implementation of character education. The environment in this case provides a high influence on the formation of student character. Narwanti 
(2011:58) explains that the level of achievement of the character education program run in schools depends on the environment. In her opinion, schools, in this case, should be thought of programs that support the achievement of the activity of character values in school.

Another problem is lack of clarity. It is related to the change that is expected from character education. Some teachers had shared that they needed more guidelines on what was important and on which characters should be focused on. In addition, this issue of lack of clarity is compounded by the contested nature of "character". Unlike academic subjects like languages or sciences where basic rules or laws are constant with little room for deviations, values of character are widely contested, leaving a lot of room for teacher gate keeping. What constitutes a moral individual or a good citizen varies from teacher to teacher. To solve the problem, Evans (1996) contends that in order "for reform to work, everyone involved must be clear about its purposes, policies, and procedures," and change agents had to "relentlessly explain, clarify, train, seek feedback, trouble shoot, modify, re-explain and re-clarify" about the change (p. 77).

The lack of clarity of what character education entails has resulted in a myriad of interpretations by teachers. After all, teachers have different beliefs and perceptions on the value of character education and how it should be implemented. Goodson (1991) explained that teachers "constantly import data on their own lives" into technical discussions of curriculum and school practices. To prevent and minimize multi-interpretation of character education, the study provide teacher manual that guide and direct teachers in their teaching.

The last identified problem is the examination culture. It is more than a school culture but a national culture. There should be a change of mind that characters plays important role in the success of the students' lives. Therefore, an alignment between character education and school subjects are imperatively to be mutually integrated.

\section{Conclusion}

The product of the study is mutual adaptive curriculum. it is characterized by its implementation in which adjustments to contextual needs, real and existing condition, and developmental requirements are adopted. It is due to the fact that 
curriculum could not empirically be implemented thoroughly as planned instead of being adapted to local needs. The design and content of curriculum is designed and determined by the external contexts of teaching and learning. The adaptation is carried out before and during the process of the implementation. The design of mutual adaptive curriculum is actualized in the forms of objectives, content or materials, learning experiences, and evaluations which are realized in the form of curriculum manual and instructional materials and activities for students. Despite the weaknesses and the problems that the mutual adaptive curriculum has, it has in certain extent proven to be a validated model of curriculum in character education.

\section{References}

Elkind, D., \& Sweet, F. (1997). The Socratic approach to character education. Educational Leadership, 54, 56-59.

Evans, R. (1996). The human side of school change: Reform, resistance, and the reallife problems of innovation. San Francisco: Jossey-Bass Publisher

Fertman, C., \& van Linden, J. (1999). Character education: An essential ingredient for youth leadership development. NASSP Bulletin, 83, 9-10.

Goodson, I. F. (1991). Sponsoring the Teacher's Voice: teachers' lives and teacher development. Cambridge Journal of Education, 21 (1), 35-45

Lickona, T. (1992). Educating for character: How our school can teach respect and responsibility. New York: Bantam Books.

Lickona, T. (1993). The return of character education. Educational Leadership, 51, 611.

Lickona, T. (1995). Promoting character education through the center for the 4 th and 5th R's (respect and responsibility). Moral Education Forum, 20, 26-34.

Lickona, Thomas. 2012. Character Matters. Jakarta: Bumi Aksara.

Kemendiknas. 2010. Pembinaan Pendidikan Karakter di Sekolah Menengah Pertama . Jakarta: Badan Penelitian dan Pengembangan.

Kemendiknas. 2010. Pengembangan Pendidikan Budaya dan Karakter bangsa. Jakarta: Badan Penelitian dan Pengembangan.

Mathison, C. (1998). How teachers feel about character education: A descriptive study. Action in Teacher Education, 20, 29-38.

Mulyasa, E. 2011. Manajemen Pendidikan Karakter. Jakarta: Bumi Aksara Najib, Sulhan . 2010. Pendidikan Berbasis Karakter. Surabaya: Jaring Pena.

Nugroho, Widio. 2012. http://edukasi.kompasiana.com/2012/11/17/nilai-nilaikarakter-dalam permainan-tradisional-gobak-sodor-503952.html. Diunduh pada tanggal 12 Februari 2013. 
Print, Murray. 1993. Curriculum Development and Design. Australia: Allen \& Unwin Pty Ltd.

Schaeffer, E. (1998). Character education in the curriculum and beyond. The Education Digest, 63, 15-17.

Schaeffer, E. (1999). It's time for schools to implement character education. NASSP Bulletin, 83, 1-7.

Tomaselli, J., \& Golden, J. (1996). Character development in education: The ABCD's of valuing. NASSP Bulletin, 80, 66-73.

TV-One. 2011. Data Kenakalan Remaja. www. TV-One.com. diunduh pada tanggal 10 Januari 2013.

Vessels, G., \& Boyd, S. (1996). Public and constitutional support for character education. NASSP Bulletin, 83, 55-60.

Zais, Robert. S. 1976. Curriculum;t Principles and Foundation. London: Kent State niversity. 